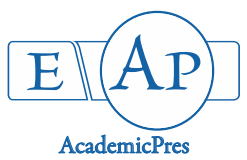

Ogugua AJ et al. (2021)

Notulae Scientia Biologicae

Volume 13, Issue 2, Article number 10811

DOI: $10.15835 / \mathrm{nsb} 13210811$

Research Article

\title{
Tubercles in cattle carcasses and risk behaviours for zoonotic tuberculosis transmission among workers in a municipal slaughterhouse
}

\author{
Akwoba J. OGUGUA ${ }^{1 *}$, Ikechukwu J. ONUNKWO ${ }^{1}$, \\ Innocent O. NWANKWO ${ }^{1}$, Leonard E. GUGU ${ }^{1}$, \\ Rose C. BASIL-EJIDIKE2 ${ }^{2}$ John A. NWANTA ${ }^{1}$ \\ ${ }^{1}$ University of Nigeria, Nsukka, Department of Veterinary Public Health and Preventive Medicine, Nigeria; \\ ogugua.akwoba@unn.edu.ng ('corresponding author); joseph.onunkwo@unn.edu.ng; innocent.nwankwo@unn.edu.ng; \\ ozonelayer3366@gmail.com; john.nwanta@unn.edu.ng \\ ${ }^{2}$ College of Veterinary Surgeons, Public Heath Specialty, Nigeria (CVSN), Nigeria; roseejidike@yahoo.com
}

\begin{abstract}
Prevalence of zoonotic tuberculosis in livestock in Nigeria contributes substantially to TB incidence among the population at risk. This study sought for tubercles in cattle carcasses and assessed knowledge and risk behaviours for zoonotic tuberculosis transmission among workers in Ikpa slaughter, Nsukka, Nigeria. Tubercle samples collected during meat inspection of 420 cattle carcasses were subjected to Ziehl Neelson stain. Questionnaire was issued to 50 slaughterhouse workers and data generated analysed with STATA 12 at $\mathrm{p}<\alpha$ (0.05). The results showed $0.71 \%$ (3/420) prevalence of tubercles that translated to $0.79 \%$ (3/382), $0.81 \%$ (3/372), 0.79\% (2/379) among the males, adults and White Fulani breeds, respectively. Among the respondents, 64\% (32/50) had good knowledge of the disease. Knowledge of ZTB was significantly associated with level of education $(\mathrm{P}<0.05)$. Practices that expose to zoonotic tuberculosis infection were found among $48 \%$ of the participants. Practices that expose to the infection was found to be significantly associated with the level of education $(\mathrm{P}<0.05)$. Tubercles were prevalent in cattle carcasses in Ikpa slaughterhouse. Workers in the place need in-depth enlightenment on ZTB and its modes of transmission to reduce human exposure to the disease.
\end{abstract}

Keywords: Ikpa slaughter; knowledge; Nigeria; practices; tubercles; zoonotic tuberculosis

\section{Introduction}

In the cattle, resistance to Mycobacterium infection results in the formation of granuloma and cessation of progressive growth of the organism. The causative agent of bovine tuberculosis, M. bovis, is zoonotic and its granuloma can be a source of infection to humans when ingested (Akalu, 2017). The granuloma or tubercle is therefore targeted during meat inspection due to its role in zoonotic tuberculosis (ZTB) transmission and the associated public health importance. During standard meat inspection, tuberculous granuloma is subjected to Ziehl Neelsen stain. When found positive, the judgement for the cattle carcass is total condemnation

Received: 08 Sep 2020. Received in revised form: 13 May 2021. Accepted: 24 May 2021. Published online: 28 May 2021.

From Volume 13, Issue 1, 2021, Notulae Scientia Biologicae journal uses article numbers in place of the traditional method of continuous pagination through the volume. The journal will continue to appear quarterly, as before, with four annual numbers. 
(Herendaet al., 2011) and subsequent compensation of the owner to protect consumers. However, in poor resource countries like Nigeria, trimming of affected parts and subsequent thorough cooking of the rest of the carcass is allowed when the disease is not generalized and the lymph nodes are not affected (Herenda et al., 2011; Awah-Ndukum et al., 2012). Bovine TB therefore, is of economic importance by affecting meat production and international trade negatively. To the butcher, there is loss due to downgrading of meat or outright condemnation. To reduce the economic burden, butchers are supposed to be adequately compensated. However, this is not done resulting in butchers not complying with meat inspectors (Hambolu et al., 2013) and other measures put in place to control ZTB in slaughterhouses in Nigeria. Presence of bovine TB in cattle carcasses in the slaughterhouses therefore portends grave public health risks given the high HIV and TB prevalence in the country coupled with abattoir activities with high exposure potentials common among slaughterhouse personnel.

Practices that expose workers and consumers to zoonotic diseases in abattoirs have been recorded in many studies in Nigeria (Sa'idu et al., 2015; Shiaka et al., 2015; Adesokan et al., 2016; Njoga et al., 2018). Some of these practices include consumption of tuberculous and raw meat (Hambolu et al., 2013; Anyanwu et al., 2019), selling infected meat to consumers (Agada, 2015) and not using personal protective equipment (PPE) (Sa'idu et al., 2015; Ayoola et al., 2017; Agada et al., 2019). In addition, many abattoirs do not or employ unqualified meat inspectors. On top of all this is that government does little or nothing to protect meat consumers but considers slaughterhouses only as sources of revenues while not enforcing meat hygiene laws (Agada et al., 2019). Moreover, there is general lack of amenities that could contribute to hygiene practices in Nigerian slaughterhouses. In addition, inadequate knowledge of ZTB common among the occupationally exposed in the country results in developing attitudes and engaging in practices that expose to the disease. According to Smits and Cutler (2004), lack of knowledge is an inhibition and prevents the acceptance of control measures in population at risk contributing to incidence of ZTB in the community. Being that reports on the presence of tubercles in cattle carcasses and level of knowledge of ZTB among workers in Ikpa slaughterhouse is scarce, it becomes important to assess the level of knowledge and activities of the workers as it concerns exposure to the disease. This will provide evidence for the need to put in place control measures. Controlling ZTB transmission in slaughterhouse will go a long way in contributing to stopping the spread of tuberculosis as being advocated by the WHO.

\section{Materials and Methods}

\section{Studyarea}

The study was conducted in Ikpa slaughterhouse, Nsukka, Enugu state, Nigeria earlier described (Njoga et al., 2019).

\section{Study design, population and sample selection}

The study adopted the cross-sectional design approach which involved cattle carcasses and workers at Ikpa slaughterhouse, Nsukka, Nigeria. Meat inspection was conducted on the cattle carcasses and a survey of the knowledge and practices of the workers between May to August, 2018. The slaughterhouse has very little in terms of amenities like well laid plan and tap water that could be of use in maintaining good hygiene. All slaughter activities are conducted on the floor of slaughterhouse. The slaughterhouse is always overcrowded and the butchers use machetes freely while cutting bones or tough tissues. The butchers process infected animals with no regard to the use of PPE and engage in many practices that could expose them to zoonotic diseases.

In sampling, Nsukka was selected through balloting from the list of the three senatorial zones in the state while Ikpa slaughterhouse was chosen for having the highest number of workers and slaughter activities in the senatorial district. The carcasses were selected by systematic random sampling of one in every three while $30 \%$ 
of the workers were selected by balloting using the list of workers in the slaughterhouse. Individuals who were not in the list as workers in the slaughterhouse or less than 18 years of age were excluded. The purpose of the study was explained to the participants and that they could decline to participate with no resultant penalty. A pretested semi-structured interviewer administered standardized ZTB questionnaire (Agada, 2015) was administered to consenting respondents.

\section{Sample collection}

The Ikpa slaughterhouse was visited three times in a week for a period of three months, and meat inspection systematically conducted following standard methods (Herenda et al., 2011). Specimen(s) suspected to be tubercles with the typical granulomatous lesions were collected into polythene bags and transported to the Department of Veterinary Public Health and Preventive Medicine, University of Nigeria Nsukka laboratory where the acid-fast stain was conducted.

\section{Ziehl-Neelsen (ZN) stain, questionnaire administration and scoring}

In $\mathrm{ZN}$, Mycobacteria retain basic dye after treatment with acid-alcohol solution and this was done according to standard methods (Shrestha et al., 2005).

Scores were awarded based on the accuracy of the respondent's answers ranging from zero to one for each incorrectly and correctly answered questions respectively. Overall scores of 11 and 14 were given for ZTB questions on knowledge and practices for each respondent, respectively. A respondent was classified as knowledgeable at the score of six or above, and engaging in (poor) practices that expose to ZTB transmission for below seven.

\section{Data analysis}

Data generated were analysed using the STATA 12 (StataCorp 4905 Lakeway Drive, College Station, Texas 77845, USA). Frequencies and percentages were calculated where appropriate. The chi-square analysis was used to determine relationships between variables (presence of tubercles) and factors (age, sex, breed) of cattle carcasses. In the questionnaire study, it was also used to assess the relationship between variables (knowledge and practices) and a range of factors (including occupation, age, sex, educational levels, experience). The p-values less than $\alpha(0.05)$ were considered significant.

\section{Results}

Characteristics of cattle slaughtered and presence of tubercles in cattle carcasses examined at Ikpa slaughterhouse

Out of the total of 420 cattle examined most were bulls (90.95\%), adults (88.57) and of the White Fulani (90.24\%) breed (Table 1). Out of the 420 cattle carcasses examined, tubercles were found in $0.71 \%$. None of the parameters considered was found to be significantly associated $(p>0.05)$ with the presence of tubercles (Table 2).

\section{Demographic characteristics of the respondents}

A total of 50 persons comprising 31 (62\%) of butchers and 19 (38\%) of workers who were engaged in other duties in the slaughterhouse participated in the study. A greater proportion of them (52\%) were young within the age group of $18-39$ years, males (92\%) and had post-primary education (60\%). A higher proportion $60 \%$ of the respondents had more than 3 years' experience of working in the slaughterhouse (Table 3 ). 
Table 1. Characteristics of cattle slaughtered in Ikpa slaughterhouse

\begin{tabular}{|l|c|c|c|}
\hline \multirow{2}{*}{ Variable } & Characteristics & $\begin{array}{c}\text { Number of animals slaughtered } \\
(\mathrm{n}=420)\end{array}$ & $\begin{array}{c}\text { Percentage } \\
(\%)\end{array}$ \\
\hline \multirow{2}{*}{ Sex } & Male & 382 & 90.95 \\
\cline { 2 - 4 } & Female & 38 & 9.05 \\
\hline \multirow{2}{*}{ Age } & Adult $(>2 \mathrm{yrs})$ & 372 & 88.57 \\
\cline { 2 - 4 } & Young $(<2 \mathrm{yrs})$ & 48 & 11.43 \\
\cline { 2 - 4 } Breed & White Fulani & 379 & 90.24 \\
\cline { 2 - 4 } & Red Bororo & 35 & 8.33 \\
\hline
\end{tabular}

Table 2. Occurrence of tuberculous lesions in cattle slaughtered at Ikpa slaughterhouse

\begin{tabular}{|l|c|c|c|c|c|}
\hline \multicolumn{1}{|c|}{ Variable } & Characteristics & Positive (\%) & Negative (\%) & Chi-square & P-value \\
\hline \multirow{2}{*}{ Sex } & Male & $3(0.79)$ & $379(99.21)$ & & \\
\cline { 2 - 6 } & Female & $0(0.00)$ & $38(100)$ & 0.188 & 0.665 \\
\hline \multirow{2}{*}{ Age } & Adult & $3(0.81)$ & $369(99.19)$ & & 0.552 \\
\cline { 2 - 6 } & Young & $0(0.00)$ & $68(100)$ & 0.353 & \\
\cline { 2 - 6 } Breed & White Fulani & $3(0.79)$ & $376(99.21)$ & & 0.204 \\
\cline { 2 - 6 } & Others & $0(0.00)$ & $41(1000$ & 0.652 \\
\hline
\end{tabular}

Table 3. Demographic characteristics of the respondents at Ikpa slaughterhouse

\begin{tabular}{|l|c|c|}
\hline \multirow{2}{*}{ Variable } & Characteristics & Frequency (\%) \\
\hline \multirow{2}{*}{ Occupation } & Butchers & $31(62)$ \\
\cline { 2 - 3 } & Others & $19(38)$ \\
\hline \multirow{2}{*}{ Age } & Young & $26(52)$ \\
\cline { 2 - 3 } & Adult & $24(48)$ \\
\hline \multirow{2}{*}{ Gender } & Male & $46(92)$ \\
\cline { 2 - 3 } & Female & $20(4)$ \\
\hline \multirow{2}{*}{ Level of education } & Little education & $30(60)$ \\
\hline \multirow{2}{*}{ Level of experience } & Well educated & $20(40)$ \\
\cline { 2 - 3 } & Few years of experience & $30(60)$ \\
\hline
\end{tabular}

\section{Knowledge of ZTB among abattoir workers at Ikpa slaughterhouse}

Almost $65 \%$ of the participants were knowledgeable about the disease with the proportion among butchers $(65.2 \%)$ being slightly higher than among those in other occupations (63.16\%). On ZTB knowledge related questions, 54\% knew that ZTB affects man; 44 and 24\% knew that it can be transmitted through ingestion (contaminated milk and meat) and inhalation, respectively, while $32 \%$ did not know how. On ZTB prevention related question, $70 \% \mathrm{knew}$ that $\mathrm{ZTB}$ transmission from cattle to man is preventable. Additionally, only $38 \%$ knew that ZTB in man is curable. However, while $74 \% \mathrm{knew}$ it is best cured with modern medicine, others indicated traditional medicine $(22 \%)$ and prayer (4\%). Chi-square analysis indicated knowledge of ZTB to be significantly $(\mathrm{p}=0.02)$ associated with only the level of education (Table 4$)$.

\section{Factors associated with practices that expose to ZTB among abattoir workers at Ikpa slaughterhouse}

As regards practices that expose to ZTB, about half of the respondents (48\%) demonstrated poor practices as it concerns the disease. A significantly higher number of those with primary education and less (70\%) engaged in practices that expose to the disease than those with post primary education (33.3\%). Less than half $(46 \%)$ of the respondents had history and evidence of BCG vaccination, the others practiced selfmedication (32\%), use of herbs (18\%) and prayer (4\%) on the issue of self-prevention from getting infected with ZTB. On how they handled cattle carcasses with tubercles, $44 \%$ sell it to the public, $38 \%$ allowed 
condemnation, $12 \%$ take them home for consumption while others $(6 \%)$ gave no response. On co-habitation with livestock, $24 \%$ had them in their homes while $76 \%$ didn't. Responding to the question of having regular check-up, $60 \%$ didn't while $40 \%$ did. Again, the majority of the respondents $(82 \%)$ indicated not eating while handling animals against $18 \%$ that did eat. Practices that expose to ZTB was significantly $(p=0.011)$ associated with education but not with the other factors considered (Table 5).

Table 4. Factors influencing levels of knowledge about ZTB among workers in Ikpa slaughterhouse

\begin{tabular}{|c|c|c|c|c|c|}
\hline Variable & Characteristics & $\begin{array}{l}\text { Good (\%) } \\
n=32(64)\end{array}$ & $\begin{array}{c}\text { Poor }(\%) \\
\mathrm{n}=18(36)\end{array}$ & Chi-square & p-value \\
\hline \multirow{2}{*}{ Occupation } & Butchers & $20(64.52)$ & $11(35.48)$ & & \\
\hline & Others & $12(63.16)$ & $7(36.84)$ & 0.009 & 0.923 \\
\hline \multirow{2}{*}{ Age } & Young & $16(61.54)$ & $10(38.46)$ & & \\
\hline & Old & $16(66.67)$ & $8(33.33)$ & 0.143 & 0.706 \\
\hline \multirow{2}{*}{ Gender } & Male & $29(63.04)$ & $17(36.96)$ & & \\
\hline & Female & $3(75.00)$ & $1(25.00)$ & 0.228 & 0.633 \\
\hline \multirow{2}{*}{$\begin{array}{l}\text { Level of } \\
\text { education }\end{array}$} & Low & $9(45.00)$ & $11(55.00)$ & & \\
\hline & High & $23(76.67)$ & $7(23.33)$ & 5.223 & 0.020 \\
\hline \multirow{2}{*}{$\begin{array}{l}\text { Level of } \\
\text { experience }\end{array}$} & $\begin{array}{l}\text { Few years of } \\
\text { experience }\end{array}$ & $14(70.00)$ & $6(30.00)$ & & \\
\hline & Well experienced & $18(60.00)$ & $12(40.00)$ & 0.521 & 0.470 \\
\hline
\end{tabular}

Table 5. Factors influencing behaviours that expose to ZTB among workers in Ikpa slaughterhouse

\begin{tabular}{|c|c|c|c|c|c|}
\hline Variable & Characteristics & $\begin{array}{c}\text { Good (\%) } \\
26(52)\end{array}$ & $\begin{array}{c}\text { Poor }(\%) \\
24(48)\end{array}$ & Chi-square & $\mathrm{P}$-value \\
\hline \multirow{2}{*}{ Occupation } & Butchers & $16(51.61)$ & $15(48.39)$ & & \\
\hline & Others & $10(52.63)$ & $9(47.37)$ & 0.005 & 0.944 \\
\hline \multirow{2}{*}{ Age } & Young & $12(46.15)$ & $14(53.85)$ & & \\
\hline & Old & $14(58.33)$ & $10(41.67)$ & 0.742 & 0.389 \\
\hline \multirow{2}{*}{ Gender } & Male & $23(50.00)$ & $23(50.00)$ & & \\
\hline & Female & $3(75.00)$ & $1(25.00)$ & 0.922 & 0.337 \\
\hline \multirow{2}{*}{$\begin{array}{l}\text { Level of } \\
\text { education }\end{array}$} & Low & $6(30.00)$ & $14(70.00)$ & & \\
\hline & High & $20(66.67)$ & $10(33.33)$ & 6.464 & 0.011 \\
\hline \multirow{2}{*}{$\begin{array}{l}\text { Level of } \\
\text { experience }\end{array}$} & $\begin{array}{c}\text { Few years of } \\
\text { experience }\end{array}$ & $9(45.00)$ & $11(55.00)$ & & \\
\hline & Well experienced & $17(56.67)$ & $13(43.33)$ & 0.654 & 0.419 \\
\hline
\end{tabular}

\section{Discussion}

The study found tubercles to be prevalent among the carcasses of slaughter cattle examined. This prevalence may not be unconnected to the absence of policy being pursued actively to control ZTB in livestock in Nigeria (Ejeh et al., 2013). In addition, uncontrolled movement of livestock from neighboring countries where the disease is prevalent (Egbe et al., 2013) is a common practice in Nigeria (Ogundipe, 2001). Prevalence of the disease in slaughter cattle represents economic loss to the butchers due to carcass condemnation (Ejeh et al., 2014; Sa'idu et al., 2015). It is of public health importance to the workers and meat consumers given that meat inspection is poorly conducted in Nigeria (Ejeh et al., 2013), leaving the consumers at the mercy of unscrupulous butchers whose major interests are in the making of profits. In fact, this study found that $44 \%$ of the respondents sell carcasses with tubercles to consumers just as earlier recorded in other studies in Nigeria (Hambolu et al., 2013; Adesokanet al., 2018). Furthermore, the Ikpa Slaughterhouses like others in Nigeria are known for being overcrowded (Agada et al., 2019) which is a factor in the transmission of ZTB (Agada, 
2015). Moreover, the free use of machetes for the cutting of Mycobacteria infected carcasses in the slaughterhouse can easily give rise to airborne droplets containing the organism which results in acquiring of the infection through inhalation (Thoenet al., 2006).

The study found more than $50 \%$ of the respondents to be knowledgeable about ZTB although with gaps. The level of knowledge of ZTB in this study is comparable to that recorded in Gusau (Ismaila et al., 2015) and Nigeria (Adesokan et al., 2018) but higher than what was reported among livestock keepers in Jigawa State, Nigeria (Ibrahim et al., 2012) and livestock workers in Lafia (Agada et al., 2019). Knowledge of ZTB among the respondents may be due to the fact that tubercles in carcasses are always targeted for condemnation by meat inspectors and the reason given to them is to protect them and the consumers from getting infected with bovine TB. Such condemnations, whether whole or partial, results to losses in revenue to the butchers. This loss is more pronounced because butchers are not compensated for meat condemnation in slaughterhouses in Nigeria (Ejeh et al., 2014). It is therefore not surprising that butchers know about ZTB more than those in other occupations since presence of tubercles in meat carcasses deprives butchers of their source of livelihood. The fact that many respondents engaged in practices that expose to ZTB infection could as well be attributed to same economic reasons given that losses due to meat condemnation (wholly borne by the butchers) is huge. Ejeh et al. (2014), recorded $\$ 18183.8$ loss due to condemnation as a result of tubercles in carcasses in one abattoir in one year in Nigeria. Therefore, many butchers would rather sell infected tissues to consumers than loss their sources of livelihood. Another major cause of poor practices may be attributed to the fact that tuberculosis is chronic and because infected individuals do not show immediate signs of the disease, many butchers do not consider ZTB to be severe enough (Hambolu et al., 2013). Belief in non-severity results in not taking personal protective measures against ZTB but engage in practices that expose to ZTB like eating tuberculous tissues (Hambolu et al., 2013) or possibly contaminated raw meat to convince customers of its palatability (Iheanacho et al., 2012). In addition, there is always the belief that the heat of cooking kills all the infectious organisms in the meat in Nigeria but this reduces rather than eliminate all hazards (Iheanacho et al., 2012). Moreover, poor and unhygienic handling of tuberculous meat in homes and food vendor kitchens can contaminate ready to eat food. Unhygienic handling is common among food vendors in Nigeria (Ogahet al., 2015) and disease outbreaks have been traced to ready to eat food sources (Hassanain et al., 2013; Fletcheret al., 2015).

The study recorded an association between level of education and knowledge of ZTB; also, between education and practices that expose to the disease. While those with high level of education were knowledgeable about the disease, those with lower level of education engaged more in TB exposing practices. This is in consonance with the findings of Adesokan et al. (2018) on ZTB among livestock workers in Nigeria as well as other studies among members of a rural community on TB in Edo State (Tobinet al., 2013), and among hospital workers in Nigeria (Ogoinaet al., 2015), members of a community on TB transmission in Tanzania (Ismail and Josephat, 2014), among TB patients about TB transmission in Bangladesh (Tasnim et al., 2012), in a community in Ethiopia on TB (Tolossaet al., 2014). The association of higher educational level with knowledge of the disease may not be unconnected to the fact that education improves one's ability to learn and acquire health knowledge; enables a healthy life style so that lack of education is regarded as sickness (Hahn and Truman, 2015). Thus "Universal Primary Education" is core strategy of the United Nations' development programme.

\section{Conclusions}

Tuberculous granuloma cases were detected among cattle inspected in Ikpa Slaughter. Most of the workers were knowledgeable about ZTB but practices that expose to the disease is rampant among them. There is need for frequent enlightenment campaign to be organized for workers at Ikpa slaughterhouse. Meat inspection in the place should be done more thoroughly and compensation paid for condemnation of ZTB 
cattle carcasses. Workers in the slaughterhouse should be screened for TB and those having the disease recommended for treatment. There should be further studies to culture, isolate and identify the Mycobacterium species responsible for the tubercles present in cattle carcasses in the slaughterhouse.

\section{Authors' Contributions}

OAJ, OJI, NJA - designed the study; GLE, BRC - collected the data, OAJ analyzed the data, drafted and wrote the manuscript, NIO revised the manuscript.

All authors read and approved the final manuscript.

Ethical approval (for researches involving animals or humans)

Ethical approval for this study was obtained from the Anambra State Ministry of Health Ethics Committee with number $\mathrm{MH} / \mathrm{AWK} / \mathrm{M} / 321 / 344$. Oral informed consent was obtained from all questionnaire participants.

\section{Acknowledgements}

This research received no specific grant from any funding agency in the public, commercial, or not-forprofit sectors.

\section{Conflict of Interests}

The authors declare that there are no conflicts of interest related to this article.

\section{References}

Adesokan, HK, Alabi PI, Ogundipe MA (2016). Prevalence and predictors of risk factors for Brucellosis transmission by meat handlers and traditional healers' risk practices in Ibadan, Nigeria. Journal of Preventive Medicine and Hygiene 57(3):E164-E171. https://doi.org/10.15167/2421-4248/jpmh2016.57.3.589

Adesokan HK, Akinseye VO, Sulaimon A (2018). Knowledge and practices about zoonotic tuberculosis prevention and associated determinants amongst livestock workers in Nigeria. PLoS One 13(6):e0198810. https://doi.org//10.1371/journal.pone.0198810

Agada CA, Mohammed J, Okoh AEJ, Ogugua AJ (2019). Occurrence of tuberculosis and predictors of zoonotic TB transmission among livestock workers in Lafia, Nigeria. Sokoto Journal of Veterinary Sciences 17(4):35-50.

Agada CA (2015). Epidemiology and public health implications of Mycobacterium tuberculosis complex and nontuberculous mycobacteria in cattle and humans in Oyo State, Nigeria. University of Ibadan. Retrieved 2019 December 4 from: https://oer.uam.edu.ng

Akalu B (2017). Review on epidemiology of bovine tuberculosis in Ethiopia. Academic Journal of Animal Diseases 6(3):57-66. https://doi.org/10.5829/idosiajad.2017.57.66

Anyanwu MU, Okorie-Kanu OJ, Ogugua AJ, Ezenduka EV, Anidebe CO (2019). Occurrence, antibiogram and vancomycin resistance of generic enterococci in horses in Nigeria. Revue de Médecine Vétérinaire 170(1-3):46-52.

Awah-Ndukum J, Kudi CA, Bradley G, Ane-AnyangweI, Titanji VPK, Fon-Tebug S, Tchoumboue J (2012). Prevalence of bovine tuberculosis in cattle in the highlands of Cameroon based on the detection of lesions in slaughtered cattle 
and tuberculin skin tests of live cattle. Veterinarni Medicina 2012(2):59-76. https://doi.org/10.17221/5252VETMED

Ayoola MC, Akinseye VO, Cadmus E, Awosanya E, Popoola OA, Akinyemi OO, ... Cadmus SI (2017). Prevalence of bovine brucellosis in slaughtered cattle and barriers to better protection of abattoir workers in Ibadan, SouthWestern Nigeria. Pan African Medical Journal 28:68. https://doi.org/10.11604/pamj.2017.28.68.10925

Egbe NF, Muwonge A, Ndip L., Kelly RF, Sander M, Tanya V, ... Asuquo A. (2013). Molecular epidemiology of Mycobacterium bovis in Cameroon. Scientific Reports 7:4652. https://doi.org/10.1038/s41598-017-04230-6

Ejeh EF, Markus IF, Ejeh AS, Musa JA, Lawan FA, Ameh JA, ... Cadmus SIB (2013). Seasonal prevalence of bovine tuberculous lesions in cattle slaughtered in Yola abattoirs. Bangladesh Journal of Veterinary Medicine 11(2):113120.

Ejeh EF, Raji MA, Bello M, Lawan FA, Francis MI, Kudi AC, Cadmus SIB (2014). Prevalence and Direct economic losses from bovine tuberculosis in Makurdi, Nigeria. Veterinary Medicine International 2014:904861. https://doi.org/10.1155/2014/904861

Fletcher S, Boonwaat L, Moore T, Chavada R, Conaly S (2015). Investigating an outbreak of staphylococcal food poisoning among travellers across two Australian states. WPSAR 6(2):17-21. https://doi.org/10.5365/wpsar.2015.6.1.011

Hahn RA, Truman BI (2015). Education improves public health and promotes health equity. International Journal of Health Services 1-22. https://doi.org/10.1177/0020731415585986

Hambolu D, Freeman J, Taddese HB (2013). Predictors of bovine TB risk behaviour amongst meat handlers in Nigeria: a cross-sectional study guided by the health belief model. PloS One 8(2):1-9. https://doi.org/10.1371/journal.pone.0056091

Hassanain NA, Hassa MA, Ahmed WM, Shaapa RM, Barakat A, El-Fadaly HA (2013). Public health importance of foodborne pathogens. World Journal of Medical Sciences 9(4):208-222. https://doi.org/10.5829/idosi.wjms.2013.9.4.8177

Herenda D, Chambers PG, Ettriqui A, Seneviratna P (2011). Manual on meat inspection for developing countries. FAO Animal Production and Health Paper 119. FAO, Viale delle Terme di Caracalla, 00153 Rome, Italy.

Ibrahim S, Cadmus SIB, Umoh JU, Ajogi I, Farouk UM, Abubakar UB, KudiAC (2012). Tuberculosis in humans and cattle in Jigawa State, Nigeria: risk factors analysis. Veterinary Medicine International 865924:1-5. https://doi.org/10.1155/2012/865924

Iheanacho O, Delia G, Hussni M, Dipeolu M, Poole J, Gachohi J, ... Makita K (2012). Assessment of risks to human health associated with meat from different value chains in Nigeria: using the example of the beef value chain. Report for Nigeria Integrated Animal and Human Health Management Project, pp 1-111.

Ismail A, Josephat P (2014). Knowledge and perception on tuberculosis transmission in Tanzania: Multinomial logistic regression analysis of secondary data. Tanzania Journal of Health Research 16(1). https://doi.org/dx.doi.org/10.4314/thrb.v16i1.5

Ismaila UG, Rahman HA, Saliluddin SM (2015). Knowledge on bovine tuberculosis among abattoir workers in Gusau, Zamfara State, Nigeria. International Journal of Public Health and Clinical Services 2(3):45-58.

Njoga EO, Nwankwo IO, Ugwunwarua JC (2019). Epidemiology of thermotolerant Campylobacter infection in poultry in Nsukka agricultural zone, Nigeria. International Journal of One Health 5:92-98. https://doi.org/10.14202/ijoh.2019.92-98

Njoga EO, Onunkwo JI, Ekere SO, Njoga U, Okoro WN (2018). Sero-epidemiology of equine brucellosis and role of horse carcass processors in spread of Brucella infection in Enugu State, Nigeria. International Journal of Current Research and Review 39-35. https://doi.org/10.7324/IJCRR.2018.10106

Ogah JO, Adekunle OC, Adegoke AA (2015). Prevalence of salmonellosis among food handlers and the health implications on the food consumers in Lagos State, Nigeria. Journal of Medical Microbiology and Diagnosis 4(2):4-8. https://doi.org/10.4172/21610703.1000187

Ogoina D, Pondei K, Chima G, Isichei C, Gidado S (2015). Knowledge, attitude and practice of standard precautions of infection control by hospital workers in two tertiary hospitals in Nigeria. Journal of Infection and Prevention 16(1):16-22. https://doi.org/10.1177/1757177414558957

Ogundipe GAT (2001). The roles of veterinary quarantine services in monitoring the movements of animals and disease prevention in Nigeria. Nigerian Veterinary Journal 23(1):1-15. 
Sa'idu AS, Okolocha EC, Dzikwi AA, Gamawa AA, Ibrahim S, Kwaga JKP, ... Maigari SA (2015). Public health implications and risk factors assessment of Mycobacterium bovis infections among abattoir personnel in Bauchi State, Nigeria. Journal of Veterinary Medicine 718193:1-5. https://doi.org/10.1155/2015/718193

Shiaka GP, Yakubu SE, Aminu-Mukhtar M, Whong CM (2015). Assessment of hygiene practices and microbial loads in Dutse ultra-modern abattoir, Jigawa State, Nigeria. Dutse Journal of Pure and Applied Sciences 1(1):104-109.

Shrestha D, Bhattacharya SK, Lekhak B, Rajendra Kuma BC (2005). Evaluation of different staining techniques (Ziehl Neelsen Stain, Kinyon Stain, Modified Cold Stain, Fluorochrome Stain) for the diagnosis of pulmonary tuberculosis. Journal of Nepal Health Research Council 3:8-16.

Smits HL, Cutler SJ (2004). Contributions of biotechnology to the control and prevention of brucellosis in Africa. African Journal of Biotechnology 631-636.

Tasnim S, Rahman A, Hoque FMA (2012). Patient's knowledge and attitude towards tuberculosis in an urban setting. Pulmonary Medicine 352850:1-5. https://doi.org/10.1155/2012/352850

Thoen C, Lobue P, Kantor ID (2006). The importance of Mycobacterium bovis as a zoonosis. Veterinary Microbiology 112:339-345. https://doi.org/10.1016/j.vetmic.2005.11.047

Tobin EA, Okojie P, Isah EC (2013). Community knowledge and attitude to pulmonary tuberculosis in rural Edo state, Nigeria. Anals of African Medicine 12(3):148-154. https://doi.org/10.4103/1596-3519.117623

Tolossa D, Medhin G, Legesse M (2014). Community knowledge, attitude, and practices towards tuberculosis in Shinile town, Somali regional state, eastern Ethiopia: a cross-sectional study. BMC Public Health 14:1-13. https://doi.org/10.1186/1471-2458-14-804
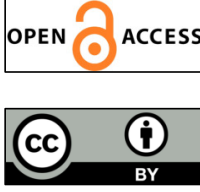

The journal offers free, immediate, and unrestricted access to peer-reviewed research and scholarly work. Users are allowed to read, download, copy, distribute, print, search, or link to the full texts of the articles, or use them for any other lawful purpose, without asking prior permission from the publisher or the author.

License - Articles published in Notulae Scientia Biologicae are Open-Access, distributed under the terms and conditions of the Creative Commons Attribution (CC BY 4.0) License.

(c) Articles by the authors; SHST, Cluj-Napoca, Romania. The journal allows the author(s) to hold the copyright/to retain publishing rights without restriction. 